\title{
Tempering the Foolish Faiths: William James and Ecology
}

\section{Wayne Viney and Madisson Mullen}

Department of Psychology, Colorado State University, Fort Collins, Colorado.

\section{Abstract}

Though William James was not an ecologist, his intellectual contributions are rich in implications for an informed philosophy of ecology. James repeatedly called attention to the importance of relations, diversity, intimacy, and the idea that everything that is genuinely real exists in an environment of other things. One of the more challenging contemporary tasks is the development of an overarching philosophical orientation that encourages ecological attitudes and studies. James's psychology and philosophy are uniquely situated to help with this task. The present work investigates ecological implications of James's pragmatism, pluralism, meliorism, and his views on the self and the world. Key Words: William JamesEcology-Ecopsychology-Environmental psychology-Relations.

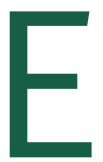

cology as a formal discipline regularly offered in university curricula surfaced long after William James did his work, but scholars now point to identifiable affinities between ecological perspectives and Jamesian metaphysics. Crosby (1996), for example, explores what he calls the ecological metaphysics of William James by amplifying James's repeated emphasis on such topics as diversity, relations, interdependence, and the interrelatedness of self and world. Heft (2001) traces James Gibson's ecological lineage to the radical empiricism of William James. Heft

(CViney and Mullen, 2017; Published by Mary Ann Liebert, Inc. This Open Access article is distributed under the terms of the Creative Commons License (http://creativecommons.org/licenses/by/4.0), which permits unrestricted use, distribution, and reproduction in any medium, provided the original work is properly credited. argues that Jamesian psychology and philosophy are key components in the intellectual heritage of ecological psychology, and he notes that ecological psychology enriches Jamesian studies. Wimberley and Pellegrino (2013) explore the pragmatic method of William James in relation to the development of an integral ecology. James's pragmatic method, according to Hogue (2010), demonstrates that knowing is a "practical, morally engaged, value-laden and value-constitutive craft, the craft of getting into right relationship with the world" (p. 137). In what follows, we hope to further identify and unpack ecological themes encountered throughout James's psychological and philosophical works. James was not an ecologist, but his mature philosophy, with its strong emphasis on intimacy, feelings, particularity, diversity, perspective, and balance, provides a relevant metaphysical frame of reference for ecology today.

There is insufficient awareness and outright denial of the growing human demands on a world that so easily sustains and destroys. It is clear that many of the problems of ecology include moral, aesthetic, psychological, social, and philosophical dimensions. Psychology in particular as a multidimensional discipline must inevitably carve out a much larger niche for itself in the ecological sciences. Many of the subdisciplinary areas of psychology bring to bear distinctive and productive ways to think and act upon ecological issues. Studies in social psychology, environmental psychology, perception and action, and belief structures are particularly relevant. Hogue (2010) notes that ecological concern is not simply with "objectified nature, in relation to which, humans stand as mere passive observers" (p. 136). Rather, we must learn to see ourselves in relation to nature in fundamentally new ways. This is consistent with a Jamesian claim that reality grows and is increasingly shaped by human activities.

In his mature philosophical works including Pragmatism, The Meaning of Truth, A Pluralistic Universe, and Essays in Radical Empiricism, James repeatedly challenges his readers to nurture beliefs deeply tuned to our relations with each other and the world. Various conceptual approaches to psychology such as Jungian psychology (Perluss, 2010) and other depth psychologies (Randall, 2012) 
JAMES AND ECOLOGY

have been explored in relation to ecopsychology, but James's work may be the most uniquely situated to articulate with and influence current developments in ecopsychology. James's work in psychology crosses some of the current divides in the field as he touches on phenomenological, qualitative, and traditional scientific approaches. His work continues to have high visibility, as every book he published with one possible exception is still in print. Jamesian scholarship thrives in the William James Society and in an outpouring of scholarly works referenced in standard database sources. As noted, others (e.g., Crosby, Heft, Hogue, Wimberly, and Pellegrino) have called attention to unique ecologically tuned features encountered in James's worldview. In what follows, implications for ecopsychology are explored in James's views of the self, his emphasis on facticity, the pragmatic theory of truth, his commitment to pluralism, and finally his moderation and meliorism.

\section{Self and World}

James (1897/1979) argued that all genuinely real beings experience that which is external (p. 111). In A Pluralistic Universe, he noted that "Everything is in an environment, a surrounding world of other things" (James, 1909/1977, p. 45). One finds in James an early conceptual treatment of object and subject relations with a focus on the conditions under which an object is experienced as an it and the conditions under which the external is experienced more intimately as a thou. Jordan (2009) notes that attachments to and intimacy with nature are central to the projects within ecopsychology. Few scholars have been so obsessed with the experience of intimacy as William James. In the opening chapter of A Pluralistic Universe, he referred to the problem of intimacy over two dozen times as he puzzled over belief structures that encourage more intimate connections with the surrounding world.

In pursuit of the question of intimacy, James acknowledged varieties of theism that change "the dead blank it of the world into a living thou" (James, 1897/1979, p. 101). However, he then spoke critically and pejoratively of some of the I-thou relations commonly encountered in classic theistic beliefs. For example, he had little patience for what he called a "theoretic drinking up" of God or a "chimerical speculative conquest" of God (James, 1897/1979, p. 111). In such cases, genuine selfhood evaporates either in blind service or in the certitude of possession of the absolute. Neither kind of fusion is consistent with the kinds of thoughtful nuanced relations James encouraged.

James's mature ecological perspective is not to be found in oneness, possession, surrender, or ownership. Our pragmatic task is not to transcend otherness, not to possess or be possessed by otherness, not to conquer or subdue it, not to fuse ourselves mystically into it, but as a first step, to simply recognize it. Kahn and Hasbach (2012) point out that "Our species always had a kinship with the Other-with a greater-than-human world" (p. 2). James believed that sensitivity to otherness with a special focus on I-it and I-thou relations and with transformations from object to subject relations can serve to promote conscious connections to other forms of sentience. Such connections, from a Jamesian perspective, are enhanced by spiritual, animistic, and mind attribution approaches to nature illustrated in contemporary work by scholars such as Roszak (1992), Snell, Simmonds, and Webster (2011), and Tam (2015).

James insisted that human consciousness is not the only or highest consciousness in the universe and that we, like "our canine and feline pets ... are tangents to the wider life of things" (James, 1907/1975, pp. 143-144). Thus, our practical task is to work cooperatively in the world with deep sensitivities to the multiplicity of legitimate interests that abound everywhere. James's statement can be thought of as a harbinger of the recent proliferation of specialized disciplinary studies in ethical theory and practice. The rapid growth of science and technology has witnessed the development of sensitivities to ethical problems that were beyond the imaginative capacities of earlier scholars. There are growing inquiries into such diverse fields as agricultural ethics (Norwood et al., 2015; Thompson, 1998; Zimdahl, 2012), animal ethics (Rollin, 1995, 2006, 2011; Singer, 1975), engineering ethics (Harris \& Pritchard, 2014), environmental ethics (Keller, 2010; Rolston, 2011), and exo-biological ethics (McLean, 2016) associated with anticipated landings in deep space and on nearby solar landscapes. James understood the importance of a broader ethical focus. He argued that something is wrong when there is a failure to seek morally informed, intimate, and satisfactory relations with the world (James, 1909/1977, p. 20).

James also explored the epistemological implications of I-thou relations. He spoke, for example, of a kind of epistemological saturation

in which the reality to be known and the power of knowing shall have become so mutually adequate that each exhaustively is absorbed by the other and the twain become one flesh, and in which the light shall somehow have soaked up all the outer darkness into its own ubiquitous beams. (James, 1897/1979, pp. 109-110)

James (1902/1985) often found such mystical epistemic unions in the religious consciousness and gave examples of this kind of relation in his classic work The Varieties of Religious Experience. The assessment of the potential benignancy or malignancy of such epistemic unions remains an important intellectual and social challenge. James (1897/ 


\section{VINEY AND MULLEN}

1979, p. 110) understood what he referred to as the charm, wildness, pang, and seductive qualities of such unions but referred to the dangers of a possible "siren strain" in apparent reference to the sea nymphs of classical mythology who lure sailors onto rocks.

A core concept in Jamesian metaphysics is that relations are as real as the things related; "the word 'or' names a genuine reality" ( James, 1909/1977, p. 146). The word "with" also names a genuine reality, and James reminds his readers that "things are "with' one another in many ways" (James, 1909/1977, p. 145). We can be "with" a thing, for example, in the sense of advocacy, adjacency, addition, attention, support, sympathy, influence, confluence, possession, accessory, companionship, observation, critical scrutiny, and so forth. Potentials for action hinge on the ways we are with things and our capacity to discern and evaluate these ways. James' philosophical perspective encourages the development of productive aesthetic, intellectual, and emotional sensitivities to the ways we are "with" each other and the world. Such sensitivity is possibly a productive precursor to the metanoia or change of heart critical to the development of a comprehensive philosophy of ecology.

James acknowledged that we exist "cheek by jowl" with forces inimical to our interests, and we also have rights. Self-defense, for example, is a right but exists parallel to an obligation to recognize the rights of inimical forces. In A Pluralistic Universe, he said "We have so many different businesses with nature ... the most a philosophy can hope for is not to lock out any interest forever (James, 1909/1977, p. 19). This includes personal interests, which must be appreciatively and critically entered into complicated ecological equations. James's nascent object and subject relations theory tempers the extremes of the I-it and I-thou orientations and calls for reflective, compassionate, and balanced distinctions. Problems surface when we are "with" things or "with" each other in destructive ways. Indifferent or distracted adjacency is as destructive as possessive ownership. The development of the wisdom of knowing how to be "with" the world is not simply adaptive for individuals and groups; it is a human survival task.

\section{Emphasis on Facticity}

Another characteristic of Jamesian empiricism, important to an ecological metaphysics, is his emphasis on facticity. James doubted that facts can be kept out of philosophy, and he argued that whether we are scientists or philosophers we believe naively in fact; he believed that facts even now are in the making (James, 1911/1996, p. 152). Facts are not frozen in time. He believed facts should occupy a prominent place at the beginning of our intellectual activities (James, 1909/1977, p. 118). In other words, our first task in any intellectual endeavor is to assess what is known and to gain an in- formed sense of the current state of affairs. James was emphatic; he used the German phrase Am Anfang war die tat to convey the idea that in the beginning was the fact; "fact is a first; to which all our conceptual handling comes as an inadequate second" (James, 1909/1977, p. 118). In Pragmatism, he referred to facts as the alpha and the omega for the tough-minded (James, 1907/1975, p. 126). James's love of facts grew out of his concern for the inertia and rigidity of entrenched absolutistic conceptual schemes. He understood that if such schemes are to be successfully challenged and changed, they must be confronted with facts. He argued that "Fact holds out blankly, brutally and blindly, against that universal deliquescence of everything into logical relations which the Absolutist Logic demands, and it is the only thing that does hold out" (James, 1912/1976, p. 140).

While James insisted on the centrality of facts, he understood that conceptual schemes are necessary abstractions constructed from and selectively cut out of events that abound in the thickness of experience. Concepts, however, are thin when compared to the copious, robust profusion of things always overflowing in the stream of experience. He argued that "Conceptual knowledge is forever inadequate to the fullness of the reality to be known" (James, 1911/1996, p. 78). Percepts, unlike concepts, tie us to the particulars, to what he called the "whats," the "thisness," and the "thatness" of things. James pointed out that "We extend our view when we insert our percepts into our conceptual map" (1911/1996, p. 78). Percepts also broaden our temporal perspective by enfranchising present events that may be relevant to prospective understandings of our world. By contrast, conceptual systems that have not been thickened up by present facts are tied too conservatively to the past and may be unresponsive to important current changes. Facticity, in a Jamesian sense, is the heart and soul of ecological science. A fact, for James, is that which will not go away; "What won't stay buried must have some genuine life" (James, 1909/1977, p. 118). There are facts, in the Jamesian sense of that word, that are obdurate, coercive, and highly pertinent to environmental ethics and to ecology. There are numerous ways to illustrate the point.

For example, roughly 70\% of the earth is covered by the oceans. Much of the remaining land mass consists of polar ice caps, high mountaintops, steep slopes, and expanding deserts that produce little or no food. The percentage of arable soil on the remaining land mass (possibly from 3\% to 6\%) is increasingly difficult to estimate because of the continuing degradation and destruction associated with deforestation, rising sea levels, urban sprawl, highway development, acidification of oceans, and erosion. The architecture of the world placed alongside human population growth uncovers another set of facts that will not stay buried. 
JAMES AND ECOLOGY

Though it now seems feasible to subtract billions from the original dismal population projections set forth in Paul Ehrlich's famous book, The Population Bomb (see Ehrlich, 1968), it is nevertheless true that we have witnessed decreasing doubling times over the past 175 years. It is a familiar claim that it took all recorded history to reach a world population in 1830 of a billion people. It took less than 100 years to reach the second billion. Doubling time for each additional billion has been diminishing. There were 5 billion people on the planet in 1986, and it took only 13 years to reach 6 billion. The figure in early 2016 was 7.3 billion, and 795 million of these did not have proper nutrition (Cook, 2016). Bartlett (2002) argues that "The greatest shortcoming of the human race is our inability to understand the exponential function" (p. 70).

It could be argued that the land use argument associated with diminishing arable soils is not an ecologically valid argument because, in theory, transitions from agricultural to non-agricultural land use could ideally be carefully planned, holistic, and integrated. Such an ideal, however, must inevitably come to terms with the reality of exceptions and compromises. James could also argue that, up to a point, diminishing acreage per person need not itself be a source of concern if there are other clearly demonstrable and viable alternatives for availability of water and food production. The potentials and the problems associated with the oceans, genetic engineering, or high-yield intensive farming (Cook, 2016; Edey, 1998, pp. 155-160) as sources of food production are all variables in the equations. In each case, a Jamesian philosophy of ecology places hard empirical work in the highest priority. The result of such work, if sufficiently compelling, is the one thing that will modify and challenge comfortable preconceptions and concepts that promote intellectual inertia.

\section{Theory of Truth}

There are productive compatibilities between ecological science and James's approach to knowledge and truth. An underappreciated centerpiece of James's pragmatic theory is that truth is always in the making. Truth is not absolutely possessed by, contained in, or restricted to a place or a time. As with the natural world, truth is dynamic, mutating, and adapting in ever changing contexts. A truth adaptive in one context may prove toxic in another context. The task, for those who would know, is to understand the temporal mobilities of truth as well as the nexus of truth in social and physical geographies. James acknowledged durable pragmatic truths, but he believed that, in time, some truths suffer rejection in whole or in part, and all truths undergo adumbrations and new applications. An opposite view, still embraced in many contem- porary cultures, is encountered in what Furcht and Hoffman (2008) refer to as "the lockdown mindset of the Middle Ages." The belief that truth is fixed or static contributes to inertia and to what Buzzell and Chalquist (2015) refer to as "dysfuntionally slow" responses to cascading and escalating environmental crises. James vehemently rejected claims, whether they be religious or political, that truth is "eternally embalmed" or that there is "absolute finality" in matters of truth (James, 1911/1996, p. 36).

Absolute finality was problematic for James because his philosophical perspective treats creation as a verb, not as a static event frozen or encapsulated in the past. Rather, creation is an ongoing, active, dynamic process marked by accidents and uncertainty; and we, for better or for worse, are now its participants. In a Jamesian view, we do not literally possess truth; we participate in it and observe and even guide some of its continuing mutations. The Jamesian pragmatic approach to truth is critical to informed ecological perspectives because he tempers our certitudes, challenges us to be responsive to change, and encourages intelligent, informed, and active engagement in the ongoing stream of life. Beliefs that truth is all collected in one place, one time, one book, or one institution and that we possess it continue to be ubiquitous, but such beliefs translate into what James referred to as "moral holidays" that foster extremist mentalities on one hand or intellectual anesthesia or inertia on the other. Life, from a Jamesian viewpoint, is like a walk; the horizon is constantly shifting; there are forever new vistas.

\section{Pluralism}

James's pragmatic and pluralistic philosophy focused largely on varieties of methods that lead to verifiable results and that productively uncover new problems and questions. For purposes of ecopsychology, pluralism could simply refer to the value of diverse and inclusive perspectives as embraced by Kahn (2013) and Wiggins, Wendt, and Ostenson (2014), who speak of "scientific and poetic accounts" (p. 5). James was deeply suspicious of definitive singular methodologies in psychology; his work can be considered as a harbinger of the work of contemporary philosophers and scientists who support pluralism and who challenge the possibility of any kind of thoroughgoing unity of the sciences (Cartright, 1999; Clarke, 1998; Gleiser, 2015). Methodologies within historical sciences such as geology and paleontology are quite different than hands-on methods employed by wet lab chemists. James valued methodological pluralism and would advise that we had better take notice if a confluence of methods, including studies of air quality, extinction rates, receding icebergs, rising oceans, and expanding deserts, all point in the same direction. 


\section{VINEY AND MULLEN}

James was also a pluralist with respect to moral questions. Such a position is especially relevant to ecological studies where there are continuing clashes with moral underpinnings. For example, shortterm economic interests are often juxtaposed against long-term environmental interests. Moralities that surface out of biological knowledge may clash with religious moralities. There are also intense confrontations over the truth-values and relevance of epistemologies such as authority, tradition, reason, and science. Ecological studies can hardly be separated from moral questions because scholarly studies that are clearly prescriptive for future generations call for action. The discovery of an "is" often has implications for an "ought."

James was also an ontological pluralist. He coined the term multiverse in 1895; a term that 120 years later is increasingly employed by physicists and astronomers (see Lloyd, 2015). He argued that, according to his pluralistic vision, there are real beginnings, real endings, real crises-many "reals" (1897/1979, p. 6). His quarrel with monistic perspectives is that they close accounts with reality prematurely and that, compared with pluralism, they are more likely to result in absolutism. He repeatedly expressed his disdain for absolutism. In a letter to Charles Renouvier in 1883 he asked "Why does the Absolute Unity make its votaries so much more conceited at having attained it, than any other supposed truth does?" (see Henry James, 1883/1920, p. 231). In The Principles of Psychology, James (1890/1981) referred to absolutism as "the great disease of philosophic thought" (p. 334).

James returns to the problem of intimacy in relation to monistic and pluralistic views. Superficially, monistic philosophies, compared with pluralism, appear to result in more intimate relations among things. If everything is part of one thing, then how can anything be really foreign, irrelevant, trivial, or secondary? In The Will to Believe, James speculated that idealism "gives to the nature of things such kinship with our own personal selves ... There is no radically alien corner, but an all-pervading intimacy" (1897/1979, p. 75). But in his more mature philosophy he came to the conclusion that intimacy depends upon some degree of externality and otherness. He noted that "The whole question of how 'one' thing can know 'another' would cease to be a real one at all in a world where otherness itself was an illusion" (James, 1912/1976, p. 30). Intimacy, from a pluralistic perspective, has its birth in the experience of the self as an agent who initiates activity, genuinely participates in the ongoing stream of events, and enjoys reciprocity. In a world that is foredone, monistic absolutism allows for integral but not intimate relations among things. James argues that monistic absolutism implies a block universe, a world without a history, with no possibilities, with a fixed future (e.g., see James, 1909/1977, p. 140). It is also a world devoid of genuine subjects. Pluralism, with its recognition of otherness, allows for authentic and intimate subject-object and subject-subject relations and for a biophilic mutuality that embraces other subjects and objects but avoids absorption or selfdestroying engrossment.

\section{Meliorism}

Finally, there is another reason Jamesian philosophy can serve a useful role in the current debates over environmental and ecological issues. James's philosophy is moderate and melioristic, and these qualities serve as necessary correctives for shrill, steep, and undisciplined extreme positions. There are certainly extremes on both sides in ecological debates. For example, Malcolm Forbes (1992), referring to so-called population problems, said "It's all nonsense" (p. 25). In the same editorial he noted that "Environmental doomsayers rely more on emotion than on fact. If the earth's air is so foul, why do we continue to live longer and longer?" (p. 25). The logic underlying such a statement makes excellent grist for students in any course in critical thinking. On the other hand, there are prophets of doom who deliver secular apocalyptic sermons every bit the equal of Jonathan Edwards' famous sermon "Sinners in the Hands of an Angry God." For example, Smith, Lyons, and Moore (1998) in their book Global Meltdown quote from Konrad Lorenz, who said that

the prospects for a human future are exceptionally dismal ... every human remains in peril of a slow death through poisoning and desiccating the environment in which he lives and by which he is sustained. Even if just in time, humans should somehow impose a check on their blind and unbelievably stupid conduct, they still remain threatened by a progressive decline in all those attributes and attainments that constitute their humanity. (p. 1)

Smith, Lyons, and Moore go on to speak of the coming hell on our wounded earth brought about partly by our ecological stupidity and partly by the rising fundamentalisms, each promising its own strained and narrow path to salvation for the remnant of the species who have been properly washed.

James believed in a world with "doors and windows open to possibilities uncontrollable in advance” (1911/1996, p. 141). He believed the world "may be saved on condition that its parts shall do their best. But shipwreck in detail, or even on the whole, is among the open possibilities" (1911/1996, p. 142). In A Pluralistic Universe he affirms his faith in self-reparation, in disconnections "remedied in part by our behavior" (James, 1909/1977, p. 148). He rejected intellectualist claims that "in every respect the universe is finished in 
advance of our dealing with it" (James, 1911/1996, p. 222). His position was that the "character of the world's results may in part depend upon our acts" ( James, 1911/1996, p. 223). The world's success, he says, "hangs on an if, or on a lot of ifs" (1911/1996, p. 229).

As individual members of a pluralistic universe, we must recognize that, even though we do our best, the other factors will have a voice in the final result. If they refuse to conspire, our good will and labor may be thrown away. No insurance-company can here cover us from the risks we run in being part of such a world. (James, 1911/1996, p. 229)

But we may hope that "The long run of experience may weed out the more foolish faiths ... without the wiser faiths ... the world [can] never be perfected" (James, 1911/1996, p. 231).

James's pluralism and meliorism call for an understanding of the risks, in our attempts to see more and better and to take seriously our role in the scheme of things. He calls for the development of a deep sense of our contingency and of our relationships with each other and with the world. In one of his speeches, he reminded his audience of all the "innocent beasts [who] have had to suffer in cattle cars and slaughter pens and lay down their lives that we may grow up, all fatted and clad, to sit together here in comfort and carry on this discourse." He goes on to ask whether this does not put "our relation to the universe in a solemn light ... To hear this question is to answer it in but one possible way, if one have a normally constituted heart" (James, 1897/1979, pp. 47-48). James's philosophy calls for thoughtful reverence as an alternative to blind zealotry, for disciplined optimism and meliorism as alternatives to despair, and for a strenuous activism that recognizes the plurality of legitimate claims in our world.

\section{REFERENCES}

Bartlett, A. A. (2002). Arithmetic, population, and energy [Videotape]. Available from Department of Information Technology Services, University of Colorado at Boulder, Boulder, CO.

Buzzell, L., \& Chalquist, C. (2015). Ecopsychology and the long emergency: Fostering sanity as the world goes crazy. Ecopsychology, 7, 183-184.

Cartright, N. (1999). The dappled world: A study of the boundaries of science. Cambridge, UK: Cambridge University Press.

Clarke, S. (1998). Metaphysics and the disunity of scientific knowledge. Brookfield, VT: Ashgate.

Cook, T. (2016). How to feed 11 billion people: Addressing the 21st century's biggest challenge. Earth, 61, 80-87.

Crosby, D. A. (1996). Experience as reality: The ecological metaphysics of William James. In D. A. Crosby \& C. D. Hardwick (Eds.), Religious experience and ecological responsibility (pp. 67-87). New York: Peter Lang.
Edey, A. (1998). Solviva: How to grow $\$ 500,000$ on one acre \& peace on earth. Martha's Vineyard, MA: Trailblazer Press.

Ehrlich, P. R. (1968). The population bomb. New York: Ballantine Books.

Forbes, M. S., Jr. (1992). Fact and comment. Forbes, 149, 25-26.

Furcht, L., \& Hoffman, W. (2008). The stem cell dilemma. New York: Arcade Publishing. Gleiser, M. (2015). Unification. In John Brockman (Ed.), This idea must die (pp. 5-8). New York: Harper Perennial.

Harris, C. E., Jr., \& Pritchard, M. S. (2014). Engineering ethics. Boston, MA: Wadsworth.

Heft, H. (2001). Ecological psychology in context: James Gibson, Roger Barker, and the legacy of William James's radical empiricism. Mahwah, NJ: Lawrence Erlbaum.

Hogue, M. S. (2010). Aesthetics: The art of ecological responsibility. American Journal of Theology and Philosophy, 31, 136-146.

James, H. (Ed.). (1920). Letters of William James (Vol. 2). Boston, MA: The Atlantic Monthly Press. (Original work published 1883)

James, W. (1975). Pragmatism. Cambridge, MA: Harvard University Press. (Original work published 1907)

James, W. (1976). Essays in Radical Empiricism. Cambridge, MA: Harvard University Press. (Original work published 1912)

James, W. (1977). A Pluralistic Universe. Cambridge, MA: Harvard University Press. (Original work published 1909)

James, W. (1979). The will to believe: And other essays in popular philosophy. Cambridge, MA: Harvard University Press. (Original work published 1897)

James, W. (1981). The principles of psychology (Vol. 1). Cambridge, MA: Harvard University Press. (Original work published 1890)

James, W. (1985). The varieties of religious experience. Cambridge, MA: Harvard University Press. (Original work published 1902)

James, W. (1996). Some problems of philosophy. Lincoln, NE: The University of Nebraska Press. (Original work published 1911)

Jordan, M. (2009). Nature and self-An ambivalent attachment? Ecopsychology, 1, 26-31.

Kahn, P. H., Jr. (2013). The next phase of Ecopsychology: Ideas and directions. Ecopsychology, 5, 163-166.

Kahn, P. H., Jr., \& Hasbach, P. H. (2012). Introduction. In P. H. Kahn, Jr., \& P. H. Hasbach (Eds.), Ecopsychology: Science, totems, and the technological species (pp. 1-21). Cambridge, MA: MIT Press.

Keller, D. R. (2010). Environmental ethics: The big questions. Chichester, UK: WileyBlackwell.

Lloyd, S. (2015). "The Universe." In J. B. Brockman (Ed.), This idea must die (pp. 11-14). New York: Harper Perennial.

McLean, M. R. (2016). Mars must be more than a 'back-up-Earth. Retrieved January 21, 2017, from https://www.scu.edu/ethics/all-about-ethics/mars-must-bemore-than-a-back-up-earth/

Norwood, F. B., Oltenacu, P. A., Calvo-Lorenzo, M. S., \&t Lancaster, S. (2015). Agricultural and food controversies: What everyone needs to know. New York: Oxford University Press.

Perluss, B. (2010). Review of Edge of the sacred: Jung, psyche, and earth by David Tracey. Ecopsychology, 2, 47-49.

Randall, R. (2012). What is nature? Comments on the special section "Depth psychology and ecopsychology." Ecopsychology, 4, 169-171.

Rollin, B. (1995). Farm animal welfare. Aims, IA: lowa State University Press.

Rollin, B. (2006). Animal rights and human morality (3rd ed.). Amherst, NY: Prometheus. 


\section{VINEY AND MULLEN}

Rollin, B. (2011). Putting the horse before Descartes: My life's work on behalf of animals. Philadelphia, PA: Temple University Press.

Rolston, H., III. (2011). A new environmental ethics: The next millennium for life on earth. New York: Routledge.

Roszak, T. (1992). The voice of the earth. New York: Simon \& Schuster.

Singer, P. (1975). Animal liberation. New York: Harper.

Smith, J. L., Lyons, G., \& Moore, E. (1998). Global meltdown: Immigration, multiculturalism, and national breakdown in the new world order. Westport, CN: Praeger.

Snell, T. L., Simmonds, J. G., \& Webster, R. S. (2011). Spirituality in the work of Theodore Roszak: Implications for contemporary ecopsychology. Ecopsychology, 3, 105-113.

Tam, K.-P. (2015). Mind attribution to nature and proenvironmental behavior. Ecopsychology, 7, 87-95.

Thompson, P. (1998). Agricultural ethics: Research, teaching, and public policy. Aims, IA: lowa State University Press.

Wiggins, B. J., Wendt, D. C., \& Ostenson, J. A. (2014). A pluralistic ecopsychology: Embracing the tension between traditions and trends. Ecopsychology, 6, 5-7.
Wimberley, E. T., \&t Pellegrino, S. (2013). The relationship between integral ecology and the pragmatic method of William James. The International Journal of Science in Society, 4, 55-70.

Zimdahl, R. L. (2012). Agriculture's ethical horizon (2nd ed.). New York: Academic Press.

Address correspondence to:

Wayne Viney

Department of Psychology Colorado State University

Fort Collins, CO 80523

E-mail:wwviney@comcast.net

Received: April 16, 2016

Accepted: November 6, 2016 